\title{
Chemical, morphological, rheological and thermal properties of Solanum lycocarpum phosphorylated starches
}

\author{
Diego Palmiro Ramirez Ascheri ${ }^{1}$, Luciane Dias Pereira², Suely Miranda Cavalcante Bastos ${ }^{3}$ \\ http://dx.doi.org/10.1590/0034-737X201461040003
}

\begin{abstract}
The increasing need for starches with specific characteristics makes it important to study unconventional starches and their modifications in order to meet consumer demands. The aim of this work was to study physicochemical characteristics of native starch and phosphate starch of S. lycocarpum. Native starch was phosphated with sodium tripolyphosphate (5-11\%) added with stirring. Chemical composition, morphology, density, binding ability to cold water, swelling power and solubility index, turbidity and syneresis, rheological and calorimetric properties were determined. Phosphorus was not detected in the native sample, but the phosphating process produced modified starches with phosphorus contents of $0.015,0.092$ and $0.397 \%$, with the capacity of absorbing more water, either cold or hot. Rheological data showed the strong influence of phosphorus content on viscosity of phosphate starch, with lower pasting temperature and peak viscosity higher than those of native starch. Enthalpy was negatively correlated with the phosphorus content, requiring $9.7 ; 8.5 ; 8.1$ and $6.4 \mathrm{~kJ} \mathrm{~g}^{-1}$ of energy for the transition from the amorphous to the crystalline state for the starch granules with phosphorus contents of $0 ; 0.015 ; 0.092$ and $0.397 \%$, respectively. Cluster analysis and principal component analysis showed that starches with 0.015 and $0.092 \%$ phosphorus have similar characteristics and are different from the others. Our results show that the characteristics of phosphate modified $S$. lycocarpum starch have optimal conditions to meet the demands of raw materials, which require greater consistency in stickiness, combined with low rates of retrogradation and syneresis.
\end{abstract}

Key words: Solanum lycocarpum Saint Hillaire, wolf’s fruit, modified starch, viscosity.

\section{RESUMO}

\section{Características químicas, morfológicas, reológicas e térmicas de amidos fosfatados da Fruta- do-lobo (Solanum lycocarpum)}

Em vista da necessidade de amidos com características específicas, é fundamental o estudo de amidos não convencionais e de suas modificações, de acordo com as exigências do mercado consumidor. O objetivo deste trabalho foi estudar as características físico-químicas de amidos nativo e fosfatado da $S$. lycocarpum. O amido foi fosfatado com tripolifosfato de sódio (de 5 a 11\%), sob agitação. Determinaram-se a composição química, a morfologia, a densidade, a capacidade de ligação à água fria, o poder de inchamento e o índice de solubilidade, a turbidez e a sinerese, as propriedades reológicas e calorimétricas. Não se detectou fósforo na amostra nativa, porém, a fosfatação gerou amidos modificados com teores de fósforo de 0,015, 0,092 e 0,397\%, que se caracterizaram por absorver maior quantidade de água, a frio e a quente. Os resultados reológicos mostraram a forte influência do teor de fósforo na viscosidade dos fosfatados, apresentando temperatura de empastamento menor e viscosidade de pico maior que as do amido nativo. A

Received: 20/04/2012. Approved: 02/08/2013.

Food Engineer, Doctor of Science. Universidade Estadual de Goiás, Rodovia BR 153, 3105, Fazenda Barreiro do Meio, 75131-500, Caixa Postal 459, Anápolis, Goiás, Brasil. ascheridpr@uol.com.br (corresponding author).

Bachelor of Industrial Chemistry, Master of Science. Instituto Federal de Educação, Ciência e Tecnologia de Goiás, Campus Anápolis, Avenida Pedro Ludovico, s/n, Reny Cury, 75131-500, Anápolis, Goiás, Brasil. luciane_dpereira@hotmail.com

${ }^{3}$ Biologist, Master of Science. Universidade Estadual de Goiás, Rodovia BR 153, 3105, Fazenda Barreiro do Meio, Caixa Postal 459, 75131-500, Anápolis, Goiás, Brasil. suelymcavalcante@gmail.com 
entalpia correlacionou-se negativamente com o teor de fósforo, necessitando-se de uma energia de 9,7; 8,5; 8,1 e 6,4 kJ $\mathrm{g}^{-1}$, para a transição do estado cristalino para o amorfo, dos grânulos de amido com teores de fósforo de $0 ; 0,015 ; 0,092$ e $0,397 \%$, respectivamente. As análises de agrupamento e dos componentes principais mostraram que os amidos com 0,015 e 0,092\% de fósforo apresentam características semelhantes entre si e diferentes daquelas dos demais, concluindo-se que as características conferidas pela fosfatação ao amido da S. lycocarpum reunem ótimas condições para as exigências de determinadas matérias-primas, para as quais se desejem consistências maiores no empastamento, combinadas com baixos índices de retrogradação e sinerese.

Palavras-chave: Solanum lycocarpum Saint Hillaire, fruta-do-lobo, amidos modificados, viscosidade.

\section{INTRODUCTION}

Starch is an important ingredient for the industrial sector and is a major component of the human diet. It has diverse applications and its marketing is on the rise in many fields of industry (Limberger et al., 2008). Even so, this natural polymer requires modifications. According to Bemiller (1997), modified starches have better functional properties than natural starches, as they tend to retrograde less, their pastes are more stable during cooling and thawing and more transparent, their gels have good adhesion, improved texture and tend to form films.

Research on new unconventional starch sources and modifications is needed to find starches with rheological properties providing better quality to the final product to meet the demands of the consumer market.

Fruits of the Amazonian regions and the Brazilian Cerrado that have potential as starch sources are still little explored. For example, despite intense pharmacological use of Solanum lycocarpum Saint Hillaire, the wolf's fruit, there is little information on its starch characteristics and chemical modification, therefore, studies are necessary on its technological usefulness.

The fruit of this plant species may contain more than $20 \mathrm{~g}$ of starch per $100 \mathrm{~g}$ pulp (Junior et al., 2004). These starch granules are rounded shaped and relatively small $(16.6 \mu \mathrm{m})$, containing $29.3 \%$ amylose and their pastes have regular stability, either cold or hot (Mota et al., 2009). These characteristics are comparable with those of rice and cassava starches.

However, the major disadvantage of unconventional starches is their restricted use in industry, because of some undesirable properties. These starches may have organic (lipids, proteins, pigments, etc.) and minerals compounds derived from the extraction process, which when interacting with amylose and amylopectin, can influence their properties and performance (Chan et al., 2010).
Water absorption and solubility, for example, depend on the starch crystalline structure, i.e., inter or intramolecular interaction of hydrogen bonds, which may break in hot water, reducing micelle strength by breaking hydrogen bonds and greatly increasing water absorption, resulting in swelling and solubilization of the starch granule (Swinkels, 1996).

However, starch properties can be improved by chemical modifications. Phosphorylation with sodium tripolyphosphate acid (STPA) is one of the most commonly used chemical modification of starches, as it is a salt of a relatively low cost and a simple process (Batista et al., 2010). Phosphate groups introduced into the starch chains causes repulsion between phosphate groups on adjacent chains and increases hydration. Phosphate groups are covalently bonded to molecules of amylopectin (Noda et al., 2007). The phosphorus content is an important factor in the variation starch functional properties, including gelatinization and retrogradation (Karim et al., 2007).

A number of authors, including Sekera \& Hanna (2005); Noda et al. (2007); Limberger et al. (2008); Ratnayake \& Jackson (2008); Kurakake et al. (2009) and Batista et al. (2010), for example, paid special attention to starch modification by phosphorylation, reporting good results in physicochemical properties. Starch phosphorylation can reduce opacity and retrogradation and enhance the binding capacity in cold water, paste clarity, swelling power, solubility, temperature, gelatinization enthalpy and viscosity of starch pastes.

Starch has specific characteristics depending on the botanical origin and the degree of phosphorylation. In this study, we determined the chemical composition, shape and size of starch granules, density, binding capacity in cold water, turbidity, syneresis and viscosity of paste. We also performed the calorimetric analysis of the native starch extracted from fruits of S. lycocarpum and their starches chemically modified with sodium tripolyphosphate acid. 


\section{MATERIALS AND METHODS}

Native starch was extracted from unripe S. lycocarpum fruits. Fruits were washed, peeled, chopped and ground in a circular rotor blade mill (MA-580, Marconi, São Paulo, Brazil), with water added with $5 \mathrm{~g} \mathrm{~L}^{-1}$ sodium metabisulfite (Synth) to prevent browning. The resultant slurry was separated by sieving through 75-250 micron stainless steel screen (Bertel, São Paulo, Brazil), followed by decantation and washing with absolute ethanol (Synth) to remove fats and excess water, drying in oven with air renewal and circulation (Marconi MA-035, São Paulo, Brazil), at $45^{\circ} \mathrm{C}$ for $6 \mathrm{~h}$.

Part of the extracted starch was phosphorylated with solutions of 5, 7 and $11 \%$ sodium tripolyphosphate acid (Synth) (v/v) with stirring according to Pereira \& Ascheri (2010), yielding samples with phosphorus levels recommended by Codex Alimentarius (FAO, 2011).

The phosphorus (P) content was determined according to Brazil (2005), by spectrophotometry using a UV/visible (SP-2000UV) spectrophotometer at $420 \mathrm{~nm}$. The contents of ash (method 923.03), moisture (method 925.10), ether extract (method 920.39) and crude protein (method 960.52, 5.83 conversion factor) were analyzed according to the methods described by AOAC (2005). Crude fiber was determined according to Brazil (2005). Starch content was determined using the technique described by Cereda et al. (2004). Amylose content was determined by blue value iodometric analysis (McCready \& Hassid, 1943).

The shape and size of the starch granules were analyzed by a LEICA EC3 optical microscope (Wetzlar, Germany) and the images analyzed by the software Leica Application Suite v. LAS EZ. 2.0.0 (Leica Microsystems, 2010), which enables clear visualization of shape and estimation of size of the starch granules.

Absolute density $(\rho)$ was determined as described by Leach \& Schoch (1964) with some modifications. A $10 \mathrm{ml}$ pycnometer with known mass was used to measure the pycnometer mass with xylene (b), xylene density (d) and the pycnometer mass with xylene and starch (c), using $5 \mathrm{~g}$ starch (a) (dry basis). The absolute density was calculated by Equation 1.

$\rho=\frac{a d}{a+b-c}$

Eq 1.

The binding capacity in cold water (BCCW) was measured as described by Gilles \& Medcalf (1965). A 2.5 $\mathrm{g}$ sample was weighed into a centrifuge tube with $40 \mathrm{ml}$ of distilled water and stirred in a Dubnoff pendulum shaker (ET-053, Tecnal Piracicaba, Brazil) for $1 \mathrm{~h}$. Samples were centrifuged at $2200 \mathrm{rpm}$ for $10 \mathrm{~min}$. The supernatant was removed and the tube containing the pellet was weighed. The water bound to the starch was determined by equation 2 :

$$
\operatorname{BCCW}(\%)=100\left(\frac{\text { bound water mass }}{\text { starch massin dry basis }}\right) \quad \text { Eq } 2 .
$$

The swelling power (SP) and water solubility index (WSI) were determined according to Schoch \& Leach (1964) at temperatures ranging from 60 to $90^{\circ} \mathrm{C}$.

Turbidity and syneresis analyses of starch gel were performed according to Oliveira \& Cereda (2003). A suspension of $8 \%$ starch in water was heated to obtain a translucent gel, which was distributed into five containers of $100 \mathrm{ml}$ (approximately $20 \mathrm{ml}$ of gel per container), cooled and stored at $4{ }^{\circ} \mathrm{C}$. Turbidity was determined by absorbance at $640 \mathrm{~nm}$ in a spectrophotometer. Syneresis was determined as the percentage of water released by the gel in relation to the total mass after centrifugation at $3000 \mathrm{rpm}$ for $15 \mathrm{~min}$, during 5 days.

Viscosity was determined using a Rapid Visco Analyzer 4 (RVA Newport Scientific PTY LTD, Sydney, Australia), according to the manufacturer's recommendations. Suspensions of $2.5 \mathrm{~g}$ starch in $25 \mathrm{ml}$ of distilled water were adjusted to $14 \%$ moisture and analyzed according to the following time/temperature regime: $50{ }^{\circ} \mathrm{C} \mathrm{min}^{-1}$, heating from 50 to $95^{\circ} \mathrm{C}$ at a $6{ }^{\circ} \mathrm{C}^{-1} \mathrm{~min}$ rate, held at $95^{\circ} \mathrm{C}$ for $5 \mathrm{~min}$ and cooled from 95 to $50{ }^{\circ} \mathrm{C}$ at a $6{ }^{\circ} \mathrm{C} \mathrm{min}{ }^{-1}$ rate. Viscosity was expressed as centiPoise (cP). From the profiles generated by the RVA, we evaluated the following parameters: maximum peak viscosity, minimum viscosity after peak, breakdown viscosity (difference between the maximum viscosity and minimum viscosity of paste maintained at $95{ }^{\circ} \mathrm{C}$ for $5 \mathrm{~min}$ ), final viscosity and retrogradation (difference between final viscosity and minimum viscosity at $95{ }^{\circ} \mathrm{C}$ for $5 \mathrm{~min}$ ) and pasting temperature $\left({ }^{\circ} \mathrm{C}\right)$.

The calorimetric analysis was performed in a differential scanning calorimeter DSC Q200 (TA Instruments, New Castle, USA), according to Fakirov et. al. (1997). The calorimeter was calibrated using indium standard. For the starch gelatinization temperature, approximately $5 \mathrm{mg}$ of sample of known moisture were placed in a hermetically sealed aluminum crucible. The scanning profile with balance consisted of reading temperatures between 5 and $110^{\circ} \mathrm{C}$, with heating rate of $10^{\circ} \mathrm{C} \mathrm{min}^{-1}$ and nitrogen flow of $50 \mathrm{ml} \mathrm{m}^{-1}$. The gelatinization enthalpy was calculated using the Universal Analysis software version 4.3A.

The experiment was arranged in a completely randomized design (CRD), with only one factor. Treatments were the phosphorus levels determined, in addition to the native starch, in the different starches prepared with 5, 7 and $11 \%$ of STPA. 
The statistical analysis of the experimental data was according to Gomes (2009). Measurements of chemical composition (means of five replicates) were expressed as mean \pm standard deviation and correlation coefficient $(r)$. The effect of different phosphate levels on the chemical composition was qualitatively determined using one-way analysis of variance (ANOVA) at 5\% probability level and significant responses were compared using the Tukey's test at $5 \%$ probability level.

Experimental data from other physicochemical properties were designed based on the phosphorus content and, in some cases, adjusted to a non-linear regression exponential model according to equation 3 :

$y=a+b \exp \left( \pm x^{1 / n}\right)$

Eq 3.

where $\mathrm{y}$ is generic response function, $\mathrm{x}$ is the real variable, $\mathrm{a}, \mathrm{b}$ and $\mathrm{n}$ represent the coefficients estimated by the method of least squares, with significance assessed by the t test at $5 \%$ probability level. The fit of the nonlinear regression model was evaluated by comparing the standard error of the estimate (SEE) using the mathematical Quasi-Newton method.

A cluster analysis by type of phosphate starch was performed with the means of the variables involved in the physicochemical properties using the procedure Cluster Analysis: Joining (tree clustering) of the Statistica 8.0 software (Statsoft, 2007), which is based on the Euclidean distance. The complete linkage method was selected for grouping. Additionally, the cluster analysis was complemented by the Principal Component Analysis (PCA).

The relationship between ash, starch, amylose, BCCW, breakdown viscosity, retrogradation and variation of gelatinization enthalpy with phosphorus content was obtained with the Pearson correlation coefficient (r), at $5 \%$ probability level. The correlation coefficient was interpreted as follows (Callegari-Jacques 2003):

- If $0.00<\mathrm{r}<0.30$, there is a weak linear correlation;

- If $0.30<\mathrm{r}<0.60$, there is a moderate linear correlation;

- If $0.60<\mathrm{r}<1.00$, there is a strong linear correlation.

The statistical analyses and the graphs were performed using the Statistica 8.0 software (Statsoft, 2007).

\section{RESULTS AND DISCUSSION}

In this study, the $S$. lycocarpum native starch showed a high purity (99.31\% starch) and low levels of other fractions in its chemical composition (Table 1). Phosphorus was not detected and the content of amylose and amylopectin were 28.79 and $70.52 \%$, respectively, agreeing with the findings of Mota et al. (2009).
Table 1 shows that contents of ether extract, fiber and protein remained constant, indicating that phosphorylation was successful. However, the ANOVA detected differences in moisture content (10.97 to 8.26\%), starch (from 99.31 to $95.96 \%$ ) and amylose (28.79 to $14.05 \%)$, which decreased with phosphorus content.

There were significant differences for ash content among the modified starches, increasing approximately 10, 13 and 16 times, when the native starch was phosphorylated up to $0.015,0.092$ and $0.397 \%$ phosphorus, respectively (Table 1), showing a strong positive correlation $(r=0.921)$. These results confirm the observations made by Limberger et al. (2008) with rice starch, who argued that the relationship between ash and phosphorus levels is caused by the introduction of phosphate groups into the starch chains.

Proportionally, the ash content due to the phosphorus introduction was responsible for the decrease in starch and amylose, showing strong inverse correlation (-0.999 $<\mathrm{r}<-0.975)$ and, consequently, the increase the proportion of amylopectin $(r=0.969)$.

Because the introduction of phosphorus into $S$. lycocarpum starch changed the chemical composition, it also accounts for the changes in the physico-chemical characteristics, forming products with different properties.

The native starch granules showed a smooth surface with different sizes and shapes (Figure 1). Starch granules were rounded, elliptical, truncate and irregular in shape. In addition to these shapes, swollen granules were observed in phosphorylated starch (Figures 1B, 1C and 1D), demonstrating that the native starch undergoes apparent damage after phosphorylation, which can influence paste properties.

The average diameter and density of native starch was $27.3 \mu \mathrm{m}$ and $1.87 \mathrm{~g} \mathrm{~mL}^{-1}$ (Figure 2A), respectively. However, after phosphorylation, the diameter increased and the density decreased (up to approximately $42 \mu \mathrm{m}$ and $1.35 \mathrm{~g} \mathrm{~mL}^{-1}$, respectively) because of the swelling of the granules. The binding capacity in cold water of phosphorylated starches was also greater than the native starch (Figure 2B), from an initial BCCW value of $125.3 \%$ to $138.7,153.4$ and $175.1 \%$ for starches containing $0.015,0.092$ and $0.397 \%$, of phosphorus, respectively. The correlation between BCCW and $\mathrm{P}$ was positively strong $(r=0.928)$.

However, these starches gelatinize when heated in a large amount of water and increase in size and partially solubilize, which can be seen by the swelling power values (Figure 3A) and the water solubility index (Figure 3B) respectively, increasing with temperature. Hoover (2001) explained that this fact occurs because the starch structure breaks, leading to weakening of hydrogen bonds and interaction of water molecules with the hydroxyl groups 
Table 1. Variation in chemical composition (dry basis) of S. lycocarpum starch as a function of phosphorus content*

\begin{tabular}{|c|c|c|c|c|}
\hline \multirow{2}{*}{ Component (\%) } & \multicolumn{4}{|c|}{ phosphorus content (\%) } \\
\hline & $0.000 \pm 00^{c}$ & $0.015 \pm 00^{c}$ & $0.092 \pm 003^{b}$ & $0.397 \pm 009^{\mathrm{a}}$ \\
\hline Moisture & $10.97 \pm 0.09^{\mathrm{a}}$ & $9.01 \pm 0.19^{\mathrm{b}}$ & $8.52 \pm 0.06^{\mathrm{bc}}$ & $8.26 \pm 0.20^{c}$ \\
\hline Ash & $0.22 \pm 0.01^{\mathrm{d}}$ & $2.18 \pm 0.01^{\mathrm{c}}$ & $2.94 \pm 0.01^{\mathrm{b}}$ & $3.54 \pm 0.02^{\mathrm{a}}$ \\
\hline Ether extract & $0.08 \pm 0.01^{\mathrm{a}}$ & $0.08 \pm 0.01^{\mathrm{a}}$ & $0.09 \pm 0.01^{\mathrm{a}}$ & $0.09 \pm 0.01^{\mathrm{a}}$ \\
\hline Fiber & $0.03 \pm 0.01^{\mathrm{a}}$ & $0.04 \pm 0.01^{\mathrm{a}}$ & $0.04 \pm 0.01^{\mathrm{a}}$ & $0.04 \pm 0.01^{\mathrm{a}}$ \\
\hline Protein & $0.36 \pm 0.01^{\mathrm{a}}$ & $0.36 \pm 0.01^{\mathrm{a}}$ & $0.37 \pm 0.01^{\mathrm{a}}$ & $0.37 \pm 0.01^{\mathrm{a}}$ \\
\hline Starch & $99.31 \pm 0.01^{\mathrm{a}}$ & $97.34 \pm 0.0^{\mathrm{b}}$ & $96.58 \pm 0.01^{\mathrm{bc}}$ & $95.96 \pm 0.03^{c}$ \\
\hline Amylose & $28.79 \pm 0.10^{\mathrm{a}}$ & $18.5 \pm 0.26^{\mathrm{b}}$ & $15.33 \pm 0.27^{\mathrm{c}}$ & $14.05 \pm 0.10^{\mathrm{c}}$ \\
\hline Amylopectin ** & $70.52^{c}$ & $78.84^{\mathrm{b}}$ & $81.25^{\mathrm{a}}$ & $81.91^{\mathrm{a}}$ \\
\hline
\end{tabular}

* Means of 5 repetitions \pm standard deviation, ** Difference between starch and amylose contents.
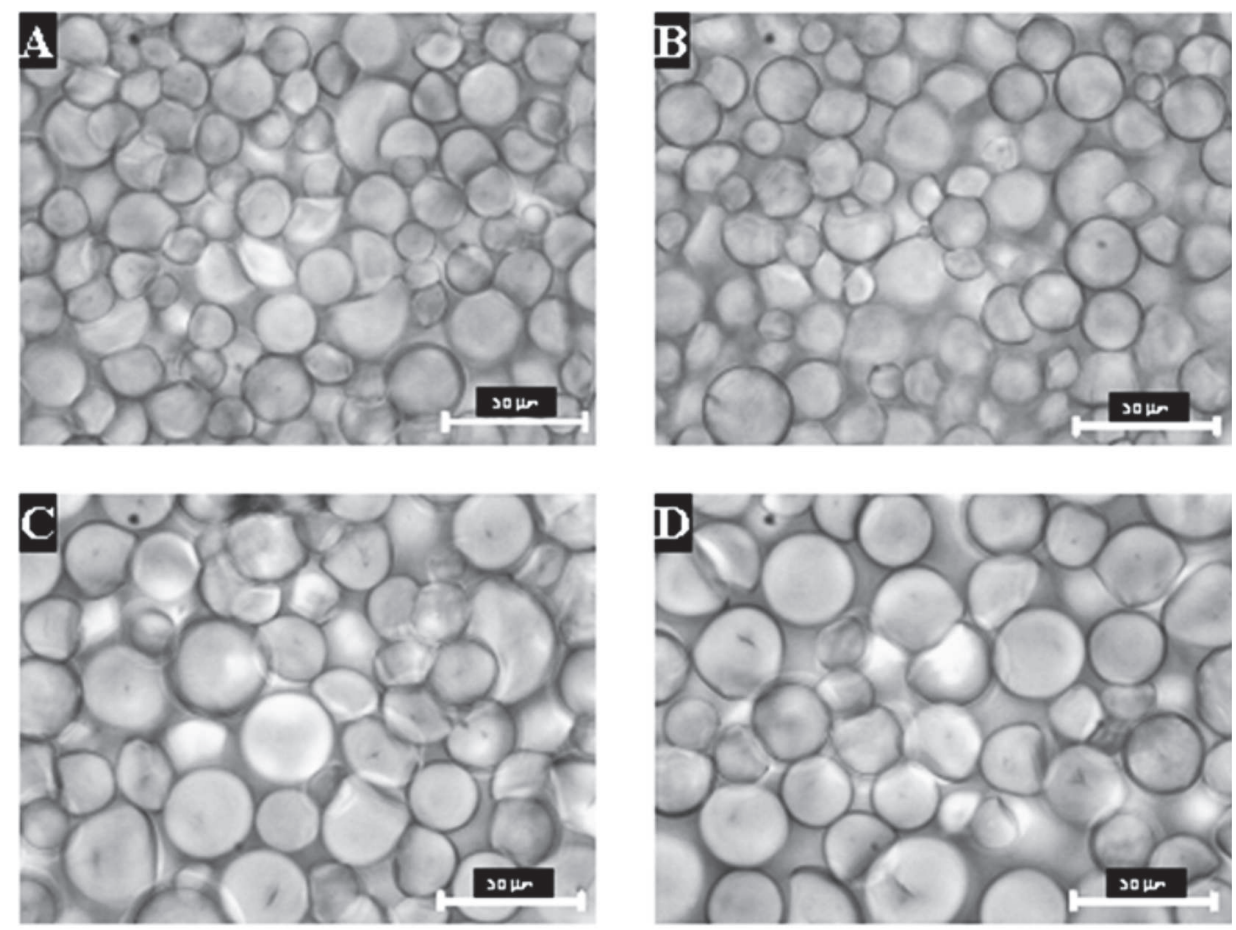

Figure 1. Microphotographs of starch extracted from unripe fruits of Solanum lycocarpum (A) native starch. Phosphate starch containing: B) $0.015 \%$, C) $0.092 \%$, and D) $0.397 \%$ phosphorus.
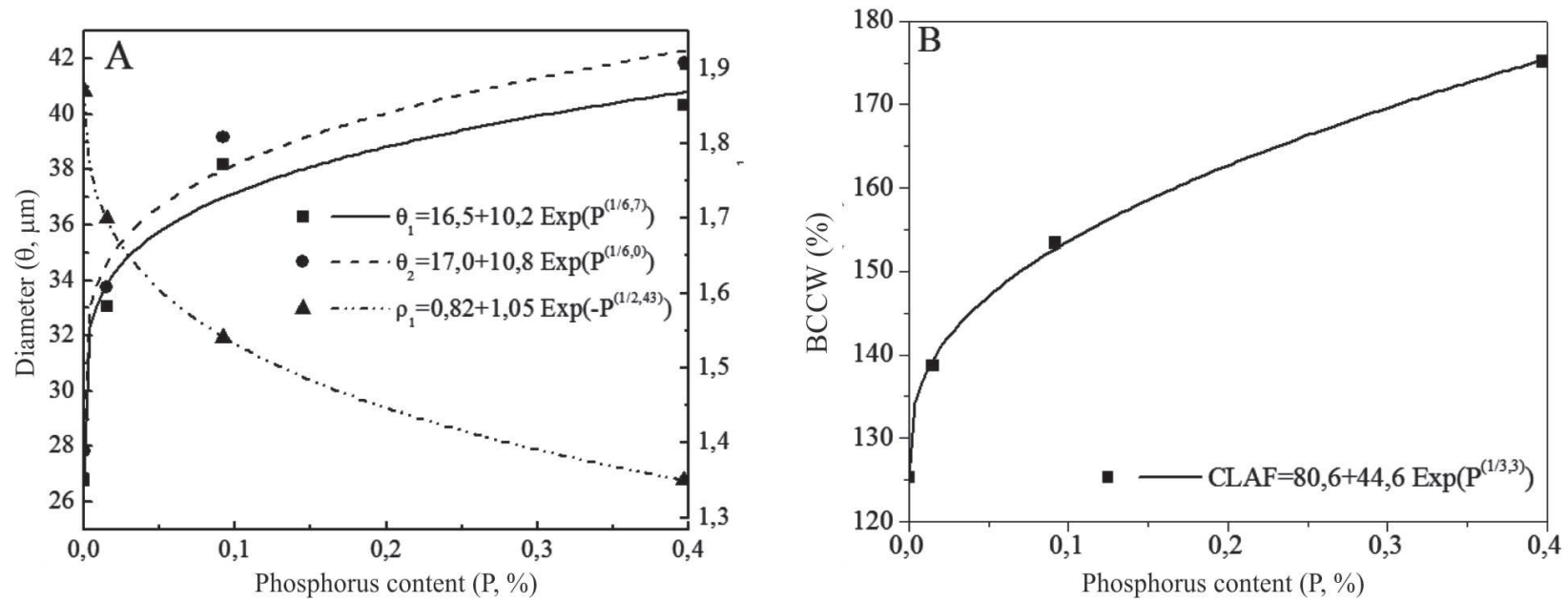

Figure 2. Effect of phosphorus content on diameter, density and binding capacity to cold water (BCCW) of starch extracted from unripe fruits of S. lycocarpum: A) smaller diameter ( $\left.\theta_{1}\right)$, larger diameter

$\left(--\theta_{2}\right)$ and density ( ... $\rho)$. B) BCCW.

Rev. Ceres, Viçosa, v. 61, n.4, p. 458-466, jul/ago, 2014 
of amylose and amylopectin, which causes swelling and partial starch solubilisation.

The introduction of phosphorus caused the swelling power and solubility index of native starch to increase (Figure 3). Daniel et al. (2006) reported that this phenomenon is due to the ability of phosphate groups to absorb larger quantities of water, that is, they have negative charges that repel each other, thus facilitating penetration and absorption of water (Wang et al., 2003).

Phosphorylated starches showed lower turbidity and syneresis than the native starch because of their higher binding capacity in cold water (Figure 4). According to Limberger et al. (2008), these starches form pastes that can be clearer and prevent retrogradation and hence syneresis, because they restrain greater contact between the amylose molecules. These molecules are solubilized during heating and leave the granule, preventing the

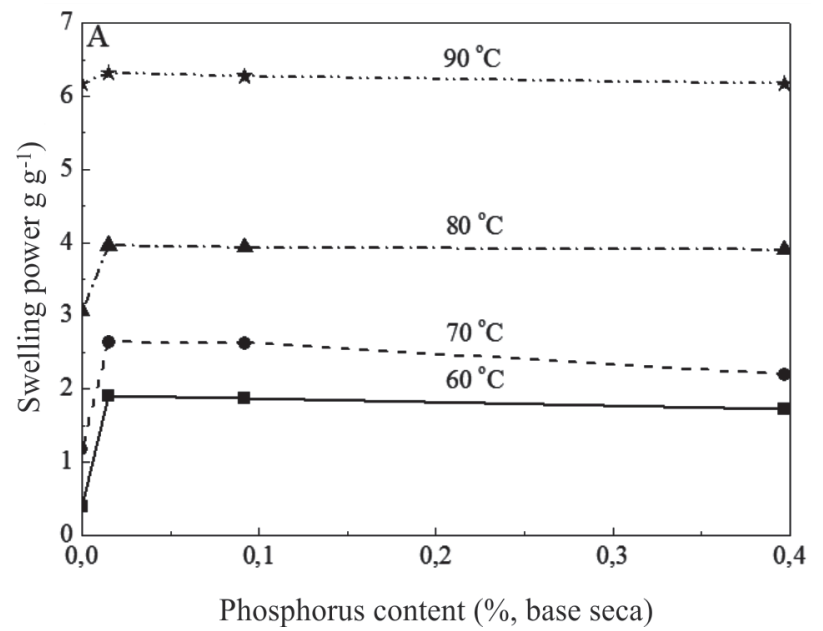

formation of micro crystals responsible for retrogradation.

The viscosity profiles (Figure 5) confirm the strong influence of phosphorus introduction on the rheological properties of phosphorylated starches. The pasting temperature of these starches was lower and the viscosity peak was higher (around $95{ }^{\circ} \mathrm{C}$ and between 6260 and $6440 \mathrm{cP}$ respectively), while for the native starch, the corresponding values were $70.7^{\circ} \mathrm{C}$ and $4407 \mathrm{cP}$. This viscosity profile was also reported for phosphorylated starches of wheat and corn (Batista et al., 2010) and starches of corn, potato and beans (Chan et al., 2010).

Batista et al. (2010) discussed that the reduction in paste temperature was due to starch gelatinization, while the maximum viscosity indicates the presence of intermolecular forces which strengthen the amorphous region of starch granules (Karim et al., 2007).

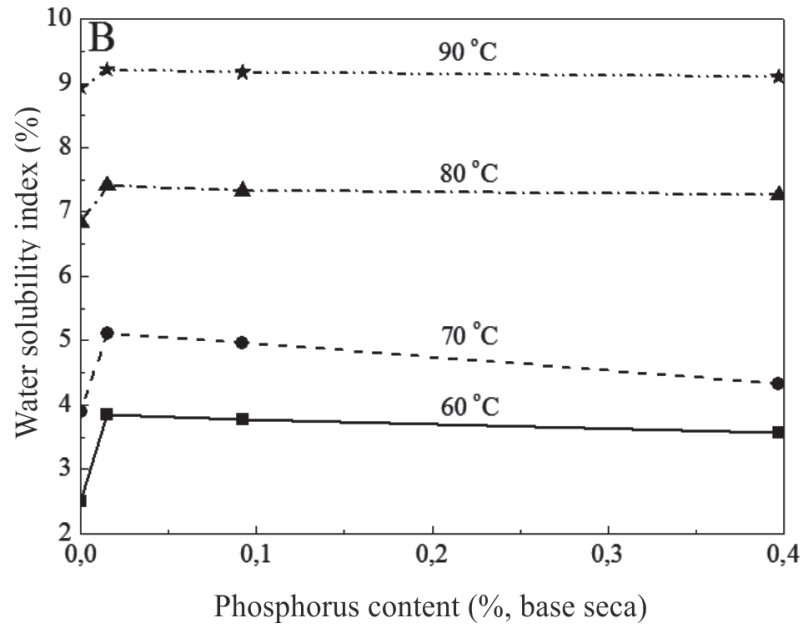

Figure 3. Variation in swelling power (A) and water solubility index (B) of S. lycocarpum starch as a function of phosphorus content and temperature.

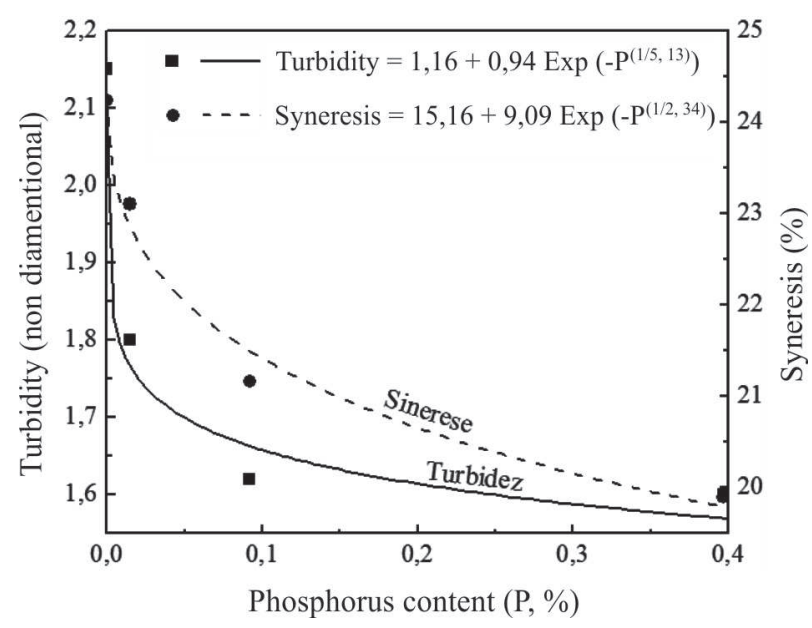

Figure 4. Variation in turbidity and syneresis of starch extracted from unripe fruits of $S$. lycocarpum as a function of phosphorus content.

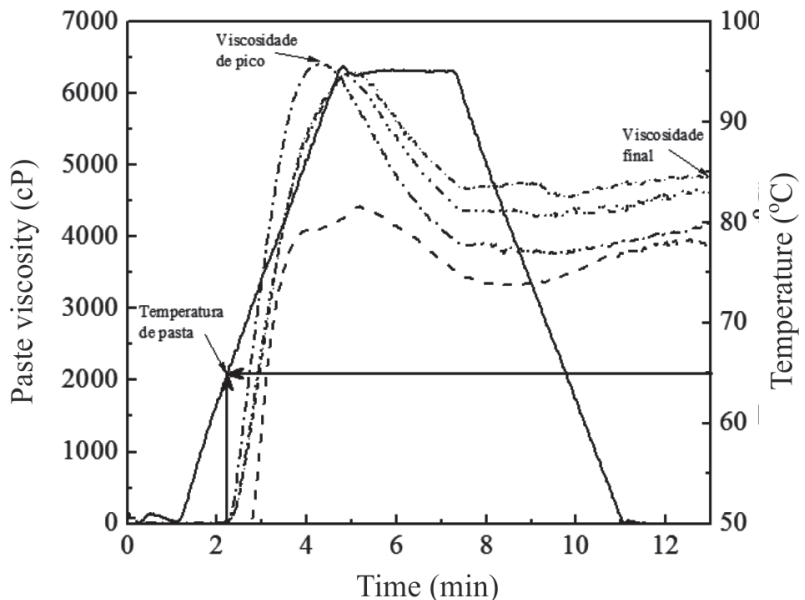

Figure 5. Temperature profiles $(3 / 4 / 4)$ and paste viscosity of starch extracted from unripe fruits of $S$. lycocarpum as a function of phosphorus content: $---0 \%, x-x-x-x 0.015 \%,-x x-x \times-$ $x \times 0.092 \%$ and $-x-x-x-x-x 0.397 \%$.

Rev. Ceres, Viçosa, v. 61, n.4, p. 458-466, jul/ago, 2014 
Although it has greater stability to heat and breakdown (breakdown viscosity of $1104 \mathrm{cP}$ ), the native starch showed higher retrogradation $(535 \mathrm{cP})$, with final viscosity of $3845 \mathrm{cP}$, whereas the phosphorylated starches showed higher breakdown viscosity (1705-2556 cP) and lower retrogradation (211-302 $\mathrm{cP}$ ) with final viscosity between 4170 and $4816 \mathrm{cP}$.

For Chan et al. (2010), the evident breakdown viscosity in modified starches compared with native starches is probably due to the weak structure of the granules during the chemical modification, which facilitates the breakdown of the granular structure, while the tendency to retrogradation is influenced by the amylose content (Singh et al., 2005), since the amylose inhibits the rearrangement of the granular structure during the cooling of the gelatinized starch paste (Singh et al., 2003).

This may have occurred in this study, however, the breakdown viscosity decreases with the phosphorus content and the relationship between the breakdown viscosity and phosphorus content was strongly negative, with $r=-0.826$. In the case of retrogradation, it showed a strong negative correlation $(r=-0.935)$ and positive correlation $(r=0.999)$ with the amylose content.

Starch thermal properties are described in Table 2. In this study, the variation in enthalpy was negatively correlated with phosphorus $(r=-0.933)$, requiring energy of 9.7, 8.5, 8.1 and $6.4 \mathrm{~J} \mathrm{~g} \mathrm{~g}^{-1}$ for the transition of starch granules with contents of $0,0.015,0.092$ and $0.397 \%$ from the crystalline to the amorphous state, respectively. Bonds with phosphorous may have caused increase in the interaction forces. According to Acquarone \& Rao (2003), inter and intra molecular bonds, in random positions in the starch granule, stabilize and strengthen the granule, and this occurs because during phosphorylation a double modification takes place, i.e., a combination of replacement with cross-linking, which hinders retrogradation (Wurzburg, 1986).

The hierarchical clustering dendrogram shows the formation of groups of genotypes with some degree of similarity and the dissimilarity among groups (Figure 6A). For a distance equal to 3 , we observe the formation of three groups: group I formed by the native starch with $0 \%$ phosphorus; Group II with starches containing 0.015 and $0.092 \%$ of phosphorus; and group III with the phosphorylated starch with $0.397 \%$ phosphorus.

In the principal components analysis all studied variables contributed to component 1 , with correlation greater than 0.70 . However, the variables that contributed most to component 2 were phosphorus content and pasting temperature.

The cluster analysis and principal component analysis were in agreement on determining similarity between starches, forming three distinct groups (Figure 6).

Table 2. Variation in thermal properties of starch extracted from unripe fruits of S. lycocarpum as a function of phosphorus content

\begin{tabular}{lccccc}
\hline $\mathbf{P}(\boldsymbol{\%})$ & $\mathbf{T}_{\mathbf{o}}\left({ }^{\mathbf{0}} \mathbf{C}\right)$ & $\mathbf{T}_{\mathbf{p}}\left({ }^{\mathbf{0}} \mathbf{C}\right)$ & $\mathbf{T}_{\mathbf{f}}\left({ }^{\mathbf{o}} \mathbf{C}\right)$ & $\Delta \mathbf{T}=\mathbf{T}_{\mathbf{f}}-\mathbf{T}_{\mathbf{o}}\left({ }^{\mathbf{0}} \mathbf{C}\right)$ & $\Delta \mathbf{H}\left(\mathbf{k J} \mathbf{k g}^{-1}\right)$ \\
\hline 0 & 62.2 & 66.1 & 75.0 & 12.8 & 9.7 \\
0.015 & 55.9 & 62.5 & 65.9 & 10.23 & 8.5 \\
0.092 & 55.6 & 61.6 & 65.6 & 10.0 & 8.1 \\
0.397 & 55.1 & 62.3 & 65.0 & 9.9 & 6.4 \\
\hline
\end{tabular}

$\mathrm{T}_{\mathrm{o}}$ : initial temperature, $\mathrm{T}_{\mathrm{p}}$ : peak temperature, $\mathrm{T}_{\mathrm{f}}$ : final temperature, $\Delta \mathrm{H}$ : variation in enthalpy and $\Delta \mathrm{t}$ : variation in temperature.
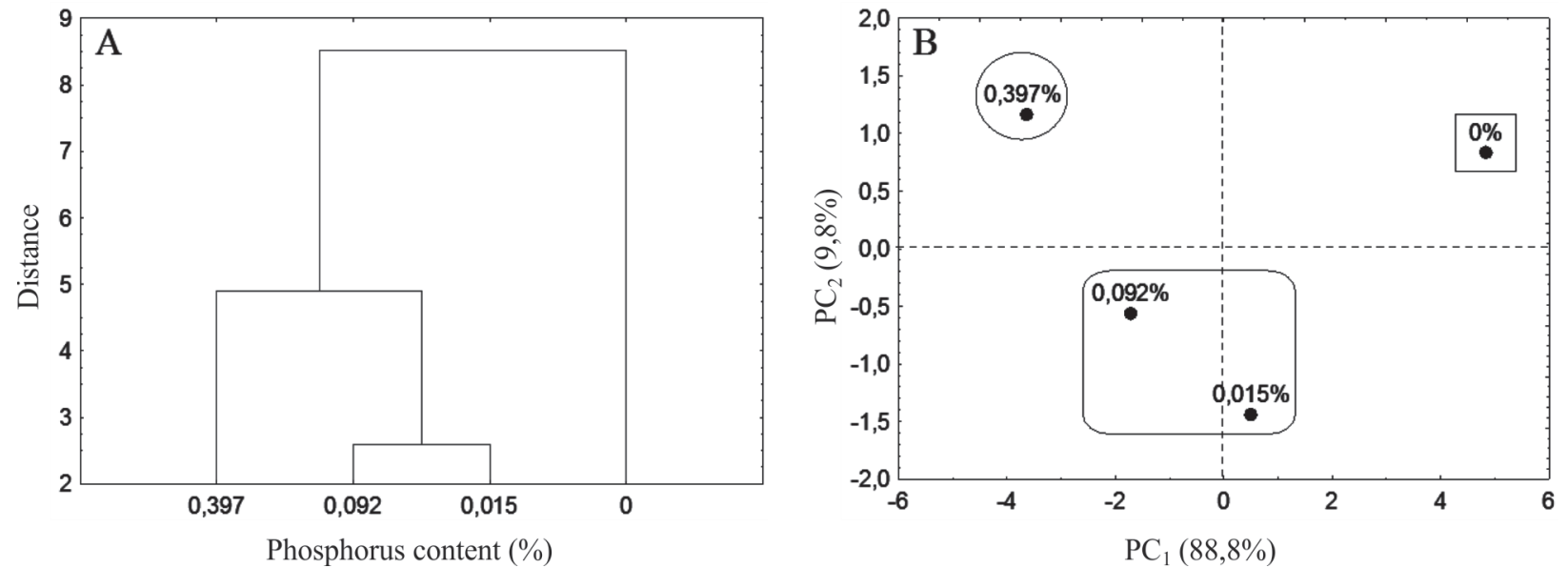

Figure 6. Cluster analysis and principal component analysis of S. lycocarpum starches as a function of phosphorus content. A) Similarity dendrogram and B) score dispersion graph of principal components (PC). 


\section{CONCLUSIONS}

Phosphorylation caused higher paste viscosity and lower degree of retrogradation in native starch of Solanum lycocarpum. The granules increased the degree of swelling, absorbing large amounts of water with the increase in phosphorus content. These characteristics allow optimal conditions to meet the requirements of certain raw materials, which need greater pasting consistency combined with low rates of retrogradation and syneresis.

The modification of Solanum lycocarpum native starch with $7 \%$ sodium tripolyphosphate acid and with 40 min stirring produces phosphate starch with $0.397 \%$ of phosphorus content, which forms pastes or gels with binding capacity in cold water of $175.1 \%$, maximum viscosity of $6440 \mathrm{cP}$, retrogradation of $211 \mathrm{cP}$, turbidity of 1.6 and syneresis of $19.8 \%$.

\section{ACKNOWLEGEMENTS}

The authors thank the State University of Goiás and Embrapa Food Technology, for the support in the analyses, the Coordination of Improvement of Higher Education Personnel (CAPES) and the Research Foundation of the State of Goiás (Fapeg) for the financial support.

\section{REFERENCES}

Acquarone VM \& Rao MA (2003) Influence of sucrose on the rheology and granule size of cross-linked waxy maize starch dispersions heated at two temperatures. Carbohydrates Polymers, 51:451-458.

AOAC (2005) Official methods of analysis of the Association of the Official Analysis Chemists. $18^{\mathrm{a}}$ ed. Arlingto, Association of Analytical Communities. 1141p.

Batista WP, Silva CEM \& Liberato MC (2010) Propriedades químicas e de pasta dos amidos de trigo e milho fosforilados. Ciência e Tecnologia de Alimentos, 30:88-93.

Bemiller JN (1997) Starch modification: challenges and prospects. Starch/Stärke, 49:31-127.

Brasil (2005) Normas analíticas do Instituto Adolfo Lutz. $4^{\mathrm{a}}$ ed. São Paulo, Instituto Adolfo Lutz. 1018p.

Callegari-Jacques SM (2003) Bioestatística: princípios e aplicações. Porto Alegre, Artemed. 255p.

Cereda MP, Daiuto ER \& Vilpoux O (2004) Metodologia de determinação de amido por digestão ácida em microondas. Revista ABAM, 2:1-1. Disponível em: <http://www.abam.com.br/revista/revista8/metodologia.php>. Acessado em: 12 de novembro de 2010 .

Chan HT, Bhat R \& Karim AA (2010) Effects of sodium dodecyl sulphate and sonication treatment on physicochemical properties of starch. Food Chemistry, 120:703-709.

Daniel AP, Bochi VC, Steffens C, Silva LP \& Emanuelli T (2006) Fracionamento a seco da farinha de aveia e modificação química da fração rica em amido. Ciência e Tecnologia de Alimentos, 26:936-943.
Fakirov S, Sarac Z, Anbar T, Boz B, Bahar I, Evstatiev M, Apostolov AA, Mark JE \& Kloczkowski A (1997) Mechanical properties and transition temperatures of crosslinked-oriented gelatin. Colloid \& Polymer Science, 275:307-314.

FAO (2011) Faostat database. Disponível em: <http:// faostat.fao.org>. Acessado em: 15 de agosto de 2011.

Gomes FP (2009) Curso de estatística experimental. 15 a ed. São Paulo, FEALQ. 451p.

Hoover R (2001) Composition, molecular structure, and physicochemical properties of tuber and root starches: a review. Carbohydrate Polymers, 45:253-267.

Junior ENO, Santos CD, Abreu CMP, Corrêa AD \& Santos JZL (2004) Alterações pós-colheita da "fruta-de-lobo" (Solanum lycocarpum st. hil.) durante o amadurecimento: análises físicoquímicas, químicas e enzimáticas. Revista Brasileira de Fruticultura, 26:410-413.

Karim AA, Toon LC, Lee VP, Ong WY, Fazilah A \& Noda T (2007) Effects of phosphorus contents on the gelatinization and retrogradation of potato starch. Journal of Food Science, 72:C132-C138.

Kurakake M, Akiyama Y, Hagiwara H \& Komaki T (2009) Effects of cross-linking and low molecular amylose on pasting characteristics of waxy corn starch. Food Chemistry, 116:6670 .

Leica Microsystems (2010) Leica application Suite version 2.0. Swizerland, Leica Microsystems Limited. CD-ROM.

Limberger VM, Silva LP, Emanuelli T, Comarela CG \& Patias LD (2008) Modificação química e física do amido de quirera de arroz para aproveitamento na indústria de alimentos. Química Nova, 31:84-88.

McCready RM \& Hassid WZ (1943). The separation and quantitative estimation of amylose and amylopectin in potato starch. Journal of the American Chemical Society, 65:11541157.

Medcalf DG \& Gilles KA (1965). Wheat starches. I. Comparison of physicochemical properties. Cereal Chemistry, 42:558-568.

Mota RDP, Ascheri DPR \& Ascheri JLR (2009). Elaboração e caracterização de filmes biodegradáveis de amido de lírio do brejo (Hedychium coronarium) e de amido de fruto-do-lobo (Solanum lycocarpum St. Hill). Revista Processos Químicos, 3:44-50.

Noda T, Kottearachchi NS, Tsuda S, Mori M, Takigawa S, MatsuuraEndo C, Kin SJ, Hashimoto N \& Yamauchi H (2007) Starch phosphorus content in potato (Solanum tuberosum L.) cultivars and its effect on other starch properties. Carbohydrate Polymers, 68:793-796.

Oliveira MA \& Cereda MP (2003) Pós-colheita de pêssegos (Prunus pérsica L. Bastsch) revestidos com filmes a base de amido como alternativa à cera comercial. Ciência e Tecnologia de Alimentos, 23:28-33.

Pereira LD \& Ascheri DPR (2010) Efeitos do tempo de reação e da concentração de tripolifosfato de sódio sobre a fosfatação do amido da Fruta-de-lobo. Revista Processos Químicos, 4:45-50.

Ratnayake WS \& Jackson DS (2008) Phase transition of crosslinked and hydroxypropylated corn (Zea mays L.) starches. LWT-Food Science and Technology, 41:346-358.

Schoch TJ \& Leach HW (1964) Swelling power and solubility of granular starches. In: Whistler RL (Ed.) Methods in carbohydrate chemistry. New York, Academic Press. p.107-108.

Sekera M \& Hanna MA (2005) Cross-linking starch at various moisture contents by phosphate substitution in an extruder. Carbohydrate Polymers, 59:541-544. 
Singh N, Kaur L \& Ezekiel R (2005) Microstructural, cooking and textural characteristics of potato (Solanum tuberosum L.) tubers in relation to physicochemical and functional properties of their flours. Journal of the Science of Food and Agriculture, $85: 1275-1284$.

Singh N, Singh J, Kaur L, Sodhi SN \& Gill BS (2003) Morphological, thermal and rheological properties of starches from different botanical sources. Food Chemistry, 81:219-231.

Statsoft (2007) Statistica (data analysis software system) version 8.0. Tulsa, StatSoft, Inc. CD-ROM.
Swinkels JJM (1996) Industrial starch chemistry: Properties, modifications and applications of starches. Veendam, AVEBE. $48 \mathrm{p}$.

Wang YJ, Truong VD \& Wang L (2003) Structures and rheological properties of corn starch as affected by acid hydrolysis. Carbohydrate Polymers, 52:321-333.

Wurzburg OB (1986) Cross-linked starches. In: Wurzburg OB (Ed.) Modified starches: Properties and uses. $4^{\mathrm{a}}$ ed. Boca Raton, CRC Press. p.41-53. 